\title{
The Public Charge Rule as Public Health Policy
}

\author{
MEDHA D. MAKHLOUF
}

\section{INTRODUCTION}

A recent Gallup poll found that health care, the economy, and immigration are the top three most important political issues for U.S. voters. ${ }^{1}$ Public charge policy — which relates to the admission of noncitizens based on the likelihood of dependence on the U.S. government for support - lies at the intersection of these three topics. At the same time, immigration and welfare reform are prominent agenda items for the current administration. ${ }^{2}$

Noncitizens are subject to a public charge determination when they apply for a visa to travel to the United States, when they arrive at a port of entry, and when they apply for lawful permanent resident status. ${ }^{3}$ On October 10, 2018, the Department of Homeland Security ("DHS") released a Notice of Proposed Rulemaking that would transform public charge policy that has existed for more than a century. ${ }^{4}$ The proposed rule would expand the application of public charge inadmissibility in several ways, such as considering an applicant's enrollment in previously-excluded public benefit programs and identifying certain characteristics as "heavily weighed" negative factors in the test. ${ }^{5}$ One analysis found ninety-four percent of noncitizens who entered the United States without lawful permanent resident status had at least one characteristic that would be weighed negatively under the proposed rule, and forty-two percent had

* J.D., Yale Law School; A.B., Brown University. Assistant Professor of Law and Director, Medical-Legal Partnership Clinic, Penn State University - Dickinson Law. I am grateful to the organizers of and participants in the Indiana Health Law Review Symposium for inspiring this Essay and to Wendy E. Parmet and Cassandra Burke Robertson for their generous and thoughtful comments. I thank Andrew Ortner for his excellent research assistance.

1. Frank Newport, Top Issues for Voters: Healthcare, Economy, Immigration, GaLluP (Nov. 2, 2018), https://news.gallup.com/poll/244367/top-issues-voters-healthcare-economyimmigration.aspx [https://perma.cc/9NGF-4MX2].

2. See, e.g., Office of Mgmt. \& Budget, Budget of the U.S. Government: A New FOUNDATION FOR AMERICAN GREATNESS 15-17 (2018), https:/www.whitehouse.gov/sites/ whitehouse.gov/files/omb/budget/fy2018/budget.pdf [https://perma.cc/7NER-E6T8].

3. Immigration and Nationality Act, 8 U.S.C. $§ 1101(a)(13)$ (2014) (defining "admission" and "admitted" to mean "the lawful entry of [an] alien into the United States after inspection and authorization by an immigration officer"); 8 U.S.C. § 1225(a)(1) (2008) (“An alien . . who arrives in the United States . . . shall be deemed for purposes of this Act an applicant for admission."). An alien who has not been admitted to the United States is subject to the inadmissibility grounds under Immigration and Nationality Act. 8 U.S.C. $§ 1255$ (2008) (relating to applications for adjustment of status to lawful permanent resident).

4. Inadmissibility on Public Charge Grounds, 83 Fed. Reg. 51,114 (Oct. 10, 2018) (to be codified at 8 C.F.R. pt. 103, 212, 213, 214, 245, and 248), https://www.govinfo.gov/content/pkg/ FR-2018-10-10/pdf/2018-21106.pdf [https://perma.cc/4KUV-3U6V].

5. $I d$. at 51,173 (proposing to consider previously excluded public benefit programs); $i d$. at 51,198 (describing heavily weighed negative factors). 
characteristics that would be considered heavily weighed negative factors. ${ }^{6}$ Common entrant characteristics that would be weighed negatively include having a household size of three or more, not having private health coverage, and not having a high school diploma-factors that have little or nothing to do with dependency on the government per se. ${ }^{7}$ The proposed rule was swiftly criticized by advocacy organizations focused on immigrants' rights, access to health care, disability rights, and workers' rights, among others. ${ }^{8}$ One category of objection to the proposed rule focuses on the negative impact on the health and welfare of the immigrant population residing in the United States. ${ }^{9}$

This essay identifies concern for public health as a factor in the development of public charge policy and demonstrates how the proposed rule abandons this rationale. Part I describes how public charge policy has remained remarkably consistent over time, even when anti-immigrant sentiment and concerns about the costs of providing public benefits to immigrants brought about restrictions on immigrant access to public benefits. Part II demonstrates how the public health rationale has influenced the development of public charge policy. Part III argues that the changes to public charge policy proposed in October 2018 represent a departure from the longstanding incorporation of public health concerns into public charge policy. I argue that the proposed changes are tied to a broader

6. Samantha Artiga et al., Estimated Impacts of the Proposed Public Charge Rule on Immigrants and Medicaid, HENRY J. KAISER FAM. FOUND. (Oct. 11, 2018), https://www.kff.org/ report-section/estimated-impacts-of-the-proposed-public-charge-rule-on-immigrants-andmedicaide-key-findings/ [https://perma.cc/YHW5-J8GX].

7. $I d$.

8. Inadmissibility on Public Charge Grounds: USCIS Proposed Rule, 19-01 IMMIGR. BRIEFINGS 1, 22 (Jan. 2019) (noting that the proposed rule "has come under fire from a number of individuals and organizations that represent or lobby on behalf of immigrants" and that "over 200,000 comments had been submitted"). See, e.g., Public Charge: A New Threat to Immigrant Families, Protecting Immigrant Families (Oct. 2018), https://www.clasp.org/sites/default/ files/2018_publiccharge_blackandwhite.pdf [https://perma.cc/97A9-CKU7] (immigrant rights); ACLU Publishes Comments Criticizing Proposed Rule on Public Charge: Trump Administration Proposal Aims to Block Immigrants with Disabilities, ACLU (Dec. 10, 2018), https://www.aclu.org/ news/aclu-publishes-comments-criticizing-proposed-rule-public-charge [https://perma.cc/GR8RUA4T] (disability rights); ACP Vows to "Do What it Takes' to Protect Immigrants" Access to Health Care, American College of Physicians (Oct. 19, 2018), https://www.acponline.org /advocacy/acp-advocate/archive/october-19-2018/acp-vows-to-do-what-it-takes-to-protectimmigrants-access-to-health-care [https://perma.cc/HCG2-DSNM] (health care access); Statement on Trump Administration's Proposed "Public Charge" Rule Denying Poor People the Opportunity for Immigration Status and Citizenship, HARVESTING Just.: A BlOG BY FARMWORKER JuST. (Sept. 24, 2018), https://www.farmworkerjustice.org/fj-blog/2018/09/statement-trump-administration-sproposed-public-charge-rule-denying-poor-people [https://perma.cc/JY8Q-JTZV] (workers' rights).

9. See, e.g., Am. Pub. Health Ass'n, Comment Letter on Proposed Rule on Inadmissibility on Public Charge Grounds (Dec. 10, 2018), https:/www.apha.org/-/media/files/pdf/advocacy/ testimonyandcomments/181210_apha_public_charge_comments.ashx?la=en\&hash=56A1 A126 FC49D31E1766368617B2284942A01B70 [https://perma.cc/5ZAP-QRPG]. 
agenda of more generally restricting access to health-supporting public benefits. Finally, I make a normative case for maintaining the current limitations on public charge policy's consideration of public benefits use by noncitizens.

\section{The Durability of Public Charge Policy Over Time}

Public charge has been a part of immigration law ever since the federal government began comprehensively regulating immigration in the late nineteenth century.$^{10}$ However, the roots of public charge can be traced to the colonial poor laws, which permitted localities to prevent from settling or removing outsiders who sought shelter or other necessities. ${ }^{11}$ In the late nineteenth and early twentieth centuries, more noncitizens were refused admission to and deported from the United States under the public charge law than under any other category of inadmissibility or deportability. ${ }^{12}$ Although public charge remains a barrier to admission for noncitizens, the percentage of noncitizens refused admission on this ground has decreased since $1940 .{ }^{13}$ Here, I trace the development of public charge law from its roots in colonial jurisdictions, to its incorporation into state law in the early years of the republic, and its ultimate expression as federal immigration law. The enduring dual principles at the heart of public charge policy are henceforth revealed: an effort to promote the entry of able-bodied and employable immigrants and, importantly, a commitment to assist members of the community who fall on hard times. ${ }^{14}$

\section{A. Historical Precedents of Public Charge Law}

Early settlers in the United States established "poor laws" that were modeled on the Elizabethan Poor Law of 1601, and the Law of Settlement and Removal of $1662 .{ }^{15}$ The purpose of the poor laws was to establish governmental authority to provide aid to the poor. ${ }^{16}$ At the time, aid came primarily in the form of shelter in almshouses (also known as poorhouses or workhouses), which also provided food, clothes, and other necessities of life. ${ }^{17}$ The poor laws categorized poor or

10. Act of Aug. 3, 1882, ch. 376, § 2, 22 Stat. 214.

11. Torrie Hester et al., Historians' Comment on Proposed Rule on Inadmissibility on Public Charge Grounds (Oct. 5, 2018), https://www.ilcm.org/wp-content/uploads/2018/10/Historianscomment-FR-2018-21106.pdf [https://perma.cc/A3HH-5WMW].

12. Id. at 3 .

13. Jeanne Batalova, Michael Fix, and Mark Greenberg, Chilling Effects: The Expected Public Charge Rule and Its Impact on Legal Immigrant Families' Public BENEFITS USE 7 (2018).

14. See Hester et al. passim, supra note 11.

15. Shapiro v. Thompson, 394 U.S. 618, 628 n.7 (1969).

16. Papachristou v. City of Jacksonville, 405 U.S. 156, 161-62 (1972) (discussing the history and purpose of the poor laws).

17. John E. Hansan, Poor Relief in Early America, VCU Libr.: Soc. Welfare Hist. PROJECT, https://socialwelfare.library.vcu.edu/programs/poor-relief-early-amer/ [https://perma. cc/L6R5-R9NM] (last modified Oct. 17, 2018). 
otherwise dependent people as "worthy (e.g., orphans, widows, handicapped, frail elderly) and ... unworthy (e.g. drunkards, shiftless, lazy)." ${ }^{18}$ These classifications determined the type of relief for which a person would qualify. ${ }^{19}$ Poor laws also established the length of time that persons must have resided in a town before they became eligible for public aid. ${ }^{20}$ Such categorizations of the "deserving" and "undeserving" poor and residency requirements persist in welfare programs to this day. ${ }^{21}$

Although almshouses were open to the merely unlucky or temporarily unemployed, they "became a refuge for the sick, the severely disabled, frail elderly, and homeless children who were unable to work and had no one to care for them." ${ }^{22}$ Dr. Victoria Sweet, a physician and historian who worked in "the last almshouse in America," writes:

At one time, almost every county in the United States had an almshouse ... as well as a county hospital. They had functioned together. The county hospital took care of the acutely ill, and the almshouse took care of the chronically disabled. In theory. In practice, the almshouse had been a catchall for everyone who didn't fit someplace else-it was a shelter, a farm for the unemployed, a halfway house, and a rehabilitation center, as well as a hospital. ${ }^{23}$

The poor laws required localities to provide for the basic needs of residents who were unable to provide for themselves. However, maintenance of almshouses was expensive. ${ }^{24}$ Therefore, the corollary to this obligation of providing assistance was the right of localities to prohibit dependent persons (or persons who were likely to become dependent) from residing in the jurisdiction if they had not already established residency at the time they became impoverished. ${ }^{25}$ The poor laws also provided the authority to expel or remove such persons from the

18. Id. See also, Elizabeth Wisner, The Puritan Background of the New England Poor Laws, 19 Soc. SERV. ReV. 381 (1945).

19. Wisner, supra note 18 , at 384.

20. See, e.g., An Act Ascertaining What Shall Constitute A Legal Settlement Of Any Person In Any Town Or District Within This Commonwealth, So As To Entitle Him To Support Therein In Case He Becomes Poor And Stands In Need Of Relief And For Repealing All Laws Heretofore Made Respecting Such Settlement, ch. 0034, 1793 Mass. Acts (“Any person, being a citizen as aforesaid and of the age of Twenty one years, who shall hereafter reside in any Town or District with this Commonwealth for the space of Ten years together and pay all State, County, Town or District taxes assessed on such person's poll or estate for any Five years within said time, shall thereby gain settlement in such Town or District.").

21. Lauren D. Appelbaum, The Influence of Perceived Deservingness on Policy Decisions Regarding Aid to the Poor, 22 Pol. Psychol. 419, 419-20 (2001).

22. Hansan, supra note 17.

23. Victoria Sweet, God's Hotel: A Doctor, a Hospital, and a Pilgrimage to the HeART OF MEDiCine 8 (2012).

24. Hansan, supra note 17.

25. Id. 
jurisdiction if they did not leave willingly. ${ }^{26}$

After the establishment of the republic, colonial poor laws were transformed into laws governing the entry of outsiders into states like New York and Massachusetts. ${ }^{27}$ The origins of poverty-related immigration restrictions in the United States lie in these individual state laws, in that they authorized noncitizen entry into the jurisdiction and enabled the deportation of noncitizen residents for specified reasons. ${ }^{28}$ For example, anti-Irish sentiment motivated the development of an 1837 law in Massachusetts which authorized the exclusion of immigrants who had been impoverished in any other country, or who suffered from health conditions that would prevent them from supporting themselves." 29 These state public charge laws were the basis for the incorporation of public charge exclusion and deportation provisions in the first federal immigration laws. ${ }^{30}$

\section{B. Public Charge in Early Immigration Law}

The first comprehensive federal immigration law, passed in 1882, included a provision denying entry to "any convict, lunatic, idiot, or any person unable to take care of himself or herself without becoming a public charge." ${ }^{31}$ In 1891, the law was broadened to exclude not only those who were unable to provide for themselves at the time of entry, but also those who were "likely to become a

26. See, e.g., The Honorable Gen. Court of Mass., Acts and Laws of the Commonwealth of Massachusetts, An Act Providing for the Relief and Support, Employment and Removal of the Poor, AND for Repealing All Former Laws Made for Those Purposes 491-92 (Boston, Wright \& Porter Printing Co. 1895).

27. See N.Y. (State) Comm'rs of emigration, Annual Reports of the Commissioners of Emigration of the State of New York: From the organization of Commission, TOGETHER WITH TABLES AND REPORTS, \& OTHER OFFICIAL DOCUMENTS. COMP. AND PREPARED UNDER RESOLUTION ADOPTED BY THE BD., AUg. 29, 1860, 12 (1861) (prohibiting the entry of "any lunatic, idiot, deaf and dumb, blind or infirm persons, not members of emigrating families, and who ... are likely to become permanently a public charge"); THE HonORABLE GEN. COURT OF MASS., Acts and Resolves Passed by the General Court of Massachusetts, An Act Relating To Alien PASSENGers 339 (Dutton and Wentworth 1850) (describing the bond or fee that shipmasters were required to pay for each arriving alien, ensuring that he or she is not "a pauper, lunatic, or idiot, or maimed, aged, infirm or destitute, or incompetent to take care of himself or herself, without becoming a public charge as a pauper"); MASS. COMM'RS OF ALIEN PASSENGERS \& ForEIGN PAUPERS, REPORT OF THE COMMISSIONERS OF ALIEN PASSENGERS AND ForEIGN PAUPERS 5-6 (1852) (regarding "the establishment of four district almshouses for the accommodation of all aliens who become a public charge upon the Commonwealth").

28. Hidetaka Hirota, Expelling the Poor: Atlantic Seaboard States and the Nineteenth-Century Origins of American Immigration Policy 180-204 (2017).

29. Id. at 55 (quoting The Honorable Gen. Court of Mass., Acts and Resolves Passed By the General Court of Massachusetts, An Act Relating To Alien Passengers 339, Dutton and Wentworth 1850).

30. Id. at 182 .

31. Act of Aug. 3, 1882, ch. 376 § 2, 22 Stat. 214 (regulating immigration). 
public charge." ${ }^{32}$ An additional provision authorized the deportation of any noncitizen who "becomes a public charge within one year after his arrival in the United States from causes existing prior to his landing therein." ${ }^{\prime 3}$ In 1917, this provision was amended to authorize the deportation of noncitizens who become a public charge within five years of arrival, which remains the law today. ${ }^{34}$ Two important insights to draw from the law of public charge deportability are: (1) that noncitizens who resided in the United States longer than one year had established residency of some sort, and were therefore no longer subject to deportability under the public charge ground; and (2) that a noncitizen would not be deported for becoming a public charge within one year for causes that arose after his or her arrival in the United States. ${ }^{35}$ Rather, such persons, having established residency or having fallen on hard times after entry, were eligible for public support.

The deportability ground was limited to noncitizens who were expected to be dependent on public aid for basic needs for the foreseeable future, with residence in public charitable institutions such as almshouses and hospitals as the paradigm of substantial dependence. ${ }^{36}$ Use of other public benefits that emerged in the early twentieth century, such as English classes or public health programs, were not considered in determinations of public charge deportability as their purpose was to integrate immigrants rather than to support them financially. ${ }^{37}$ This was true under the colonial poor laws as well as under state and early federal immigration laws. ${ }^{38}$ Although the majority of exclusions and deportations of noncitizens in the early- to mid-twentieth century were attributable to the public charge laws, historians have noted that "the number . . . remained small, especially when compared to the numbers admitted." 39

\section{The Expansion of Public Benefits}

During the twentieth century, state and federal-as opposed to local-governments became increasingly responsible for the design and administration of a broad array of public benefit programs. This shift was set in

32. 1891 Immigration Act, ch. 551, 26 Stat. 1084.

33. Id.

34. Act of Feb. 5, 1917, ch. 29, § 19, 39 Stat. 874.

35. Id.

36. Hester et al., supra note 11, at 3; IMmigration Services, ANNUAl RePort of the COMMISSIONER-GENERAL OF IMMIGRATION TO THE SECRETARY OF THE TREASURY 10 (Washington: Government Printing Office, 1896), https://babel.hathitrust.org/cgi/pt?id=osu.32435027600600; view=1up;seq=16 (stating that "no immigrant landed in this country within [Fiscal Year 1895-96] is now a burden upon any public or private institution); $i d$. (also noting that 1,946 immigrants "fell into temporary distress and became public charges" from causes arising within one year after entry, but they were not returned to their country of origin).

37. Hester et al., supra note 11 , at 4.

38. Id. at 3 .

39. Id. 
motion by the passage of the Social Security Act of $1935 .^{40}$ In addition to establishing Social Security retirement benefits, the Act created three new federal programs to provide need-based income support (what we now call "welfare") to people who fit within specified categories of the deserving poor: fatherless children, the aged, and the blind. ${ }^{41}$ The first laws to authorize permanent, federally-funded housing were also enacted in the 1930s. ${ }^{42}$ The 1960s and 1970s saw another large expansion of public benefit programs, including the establishment of Medicaid, Medicare, Food Stamps, Head Start, and job training programs and child care for parents receiving welfare. ${ }^{43}$

Throughout this period, as the array of public benefit programs expanded dramatically, the public charge ground of deportability remained a little-used provision of immigration law, in part because its main limitations are enshrined in statute: it can only be invoked for causes existing prior to entry and only for a limited period following a noncitizen's entry. ${ }^{44}$ In 1948, application of public charge deportability became even more restrictive when the Board of Immigration Appeals ("BIA"), the appellate administrative body for interpreting immigration laws, established a new three-part test in Matter of $B-.^{45}$ In order to establish that a noncitizen is deportable under the public charge ground, (1) the state must have imposed a charge upon the noncitizen for services rendered; (2) the state must have demanded payment from the noncitizen; and (3) the noncitizen must have failed to pay the charge. ${ }^{46}$ Deportations based on public charge remain rare. ${ }^{47}$

40. Social Security Act of 1935, ch. 531, 49 Stat. 620; KARen M. TANi, States of Dependency: Welfare, Rights, and American Governance, 1935-1972 3 (Cambridge University Press 2016).

41. Karen M. Tani, Administrative Equal Protection: Federalism, the Fourteenth Amendment, and the Rights of the Poor, 100 CoRNELL L. REV. 825, 829 (2015). The programs were called Aid to Dependent Children, Old Age Assistance, and Aid to the Blind. Id.

42. National Housing (Capehart) Act of 1934, ch. 847, 48 Stat. 1246 (enacted June 27, 1934); U.S. Housing (Wagner-Steagall) Act of 1937, ch. 896, 50 Stat. 888 (enacted September 1, 1937).

43. Food Stamp Act of 1964, 7 U.S.C.A. $§ 2011$ et seq. (1964); Social Security Act, 7 U.S.C.A. § 1396 (Title XIX on Medicaid); Social Security Act, 7 U.S.C.A. § 1395 (Title XVIII on Medicare); Economic Opportunity Act of 1965, Pub. L. 88-452 (creating Head Start); Social Security Act, 7 U.S.C.A. $§ 601$ et. seq. (funding child care services for parents receiving Aid to Families with Dependent Children, in order to allow them to participate in work and training programs; establishing WIN Child Care Services to enable parents receiving AFDC to participate in the Work Incentive (WIN) Program); Social Security Act, 7 U.S.C.A. $§ 1397$ a (expanding eligibility for subsidized child care to low-income families not receiving AFDC).

44. Immigration and Nationality Act, 8 U.S.C. § 1227(a)(5) (2008) (“Any alien who, within five years after the date of entry, has become a public charge from causes not affirmatively shown to have arisen since entry is deportable.").

45. Matter of B-, 3 I\&N Dec. 323 (BIA 1948).

46. Id. at 326 .

47. Field Guidance on Deportability and Inadmissibility on Public Charge Grounds, 64 Fed. Reg. 28,689, 28,691 (May 26, 1999). 
Public charge deportation policy continued to echo the dual principles described in the previous section: once noncitizens become members of the community, they are eligible to receive the full array of public benefits without any danger of being removed from the country. Historians have noted the logic behind this principle: "[t]o deport an immigrant who became ill or disabled from causes subsequent to entry would unfairly hold the country of origin responsible and contradict the intent of the inadmissibility grounds." 48 For example, during the Great Depression, the Immigration and Naturalization Service ("INS") did not consider noncitizens deportable if they received public aid on account of unemployment. ${ }^{49}$ In addition, there seemed to be an implicit recognition that access to public benefits would help to integrate immigrants and ensure their long-term self-sufficiency. Even in cases in which deportation under the public charge ground was warranted, courts frequently used their discretion to suspend deportation based on the principle of promoting integration. ${ }^{50}$

Throughout the expansion of federal public benefit programs in the twentieth century, public charge policy as it related to both inadmissibility and deportability remained remarkably consistent. ${ }^{51}$ Public charge policies in each context are distinct, but related. The dual principles underlying the policy of public charge deportability have strongly influenced the development of public charge inadmissibility: Noncitizens who are considered members of the community are eligible to receive an array of public benefits without the threat of negative immigration consequences. In both contexts, public charge determinations did not consider use of public benefits that were intended to subsidize health care (other than for long-term institutional care), housing, and food. ${ }^{52}$ Such programs were understood to supplement rather than fully provide for the basic needs of lowincome people. ${ }^{53}$ For example, receipt of public health services such as immunizations or medical treatments to ensure healthy development (prenatal care, for example) was not considered evidence of dependence. ${ }^{54}$ Only public benefit programs that provided long-term institutionalization and cash benefits

48. Hester et al., supra note 11 , at 4.

49. Mae Ngai, Impossible Subjects: Illegal Aliens and the Making of Modern America 72 (Princeton Univ. Press, 2004).

50. See Leo M. Alpert, The Alien and the Public Charge Clauses, 49 YAlE L. J. 18, 22 (1939) (describing cases in which the public charge deportability clause was not applied to noncitizen families who were supported by welfare).

51. Hester et al., supra note 11 , at 1 .

52. Field Guidance on Deportability and Inadmissibility on Public Charge Grounds, 64 Fed. Reg. 28,689 (May 26, 1999) ("It has never been Service policy that any receipt of services or benefits paid for in whole or in part from public funds renders an alien a public charge, or indicates that the alien is likely to become a public charge. The nature of the public program must be considered.").

53. Id. at 28,689, 28,692 (" $[\mathrm{N}]$ on-cash benefits (other than institutionalization for long-term care) are by their nature supplemental"); id. (excluding Food Stamps from the Department of State's public charge inadmissibility determination because of its "supplemental" nature).

54. Id. at 28,693. 
were considered in the public charge determination, as reliance on such benefits was believed to indicate substantial dependence on government support. ${ }^{55}$

In their applications for adjustment of status to lawful permanent resident, noncitizens are subject to a "totality of the circumstances" analysis in order to determine whether they are likely to become a public charge. ${ }^{56}$ Use of public benefits while living in the United States is one factor among many-including age, health, family status, education, assets, resources, and financial status - used to assess the likelihood that a noncitizen is inadmissible under the public charge ground. ${ }^{57}$ The different analyses for public charge inadmissibility and deportability reflect the forward-looking and backward-looking nature of the examinations, respectively. Public charge deportability has to do with whether a noncitizen has come to the United States without intending to rely on government support and has since become a member of the community whom the State is obligated to support. For this reason, the analysis focuses on use of certain public benefits that indicate total, or near-total, dependence on the government within a noncitizen's first five years of entry, for reasons predating that entry. ${ }^{58}$ Inadmissibility, on the other hand, is concerned with whether a noncitizen is "likely to become a public charge at some future time." 59 Therefore, the inadmissibility test assesses a broader array of factors that suggest whether a noncitizen is likely to become totally or nearly totally dependent on the government for support in the future. ${ }^{60}$

\section{Restrictions on Immigrant Eligibility for Public Benefits}

Throughout most of the twentieth century, noncitizens were generally eligible

55. Alpert, supra note 50, at 22-28 (describing residence in charitable institutions and "welfare relief" as the principal types of public assistance considered in public charge determinations); id. at 23 ("It is the type of relief today usually called general public assistance, welfare relief, or home relief, that is the modern counterpart of the pauper, almshouse and charity concept.")

56. Field Guidance on Deportability and Inadmissibility on Public Charge Grounds, 64 Fed. Reg. 28,689 (May 26, 1999).

57. Immigration and Nationality Act $\S 212(\mathrm{a})(4)(B)$; see also 9 FAM 302.8-2(B)(2)(a)(2), 302.8-2(B)(3)(a)(1) (2016).

58. See Immigration and Nationality Act $\S 241(\mathrm{a})(5)$.

59. Matter of Harutunian, 14 I\&N Dec. at 589.

60. See id. at 588 ("The administrative authorities have adopted the view that, while economic factors should be taken into account, the alien's physical and mental condition, as it affects ability to earn a living, is of major significance."); 1950 OMNIBUS REPORT OF THE SENATE Judiciary Committee, S. Rep. No. 81-1515, at 346-50 (2d Sess. 1950) ("Since the elements constituting likelihood of becoming a public charge are varied, there should be no attempt to define the term in the law, but rather to establish the specific qualification that the determination of whether an alien falls into that category rests within the discretion of the consular officers or the Commissioner."). 
for public aid. ${ }^{61}$ This included eligibility for the major benefit programs enacted in the 1960s, such as Medicaid, ${ }^{62}$ Aid to Families with Dependent Children ("AFDC," the successor program to Aid to Dependent Children), ${ }^{63}$ Food Stamps,${ }^{64}$ and federal housing assistance programs. ${ }^{65}$ In general, at the time such programs were created, eligibility criteria related to citizenship or immigration status did not exist. ${ }^{66}$ However, reform of the immigration laws in 1965 caused an increase in immigration, including among undocumented immigrants, which led to closer scrutiny of the costs of providing access to public benefits for immigrants. ${ }^{67}$ In the 1970 s, new laws began to restrict undocumented immigrants'

61. Cybelle Fox, Unauthorized Welfare: The Origins of Immigrant Status Restrictions in American Social Policy, 102 J. AM. Hist., 1051, 1057 (2016). ("Between 1935 and 1971 no federal laws barred noncitizens, even unauthorized immigrants, from social security benefits, unemployment insurance, [Old Age Assistance], or ADC . . . With the enactment of additional public assistance legislation - creating the food stamp program or Medicaid, for example - the same rules applied. Under federal law, both authorized and unauthorized immigrants were eligible for these programs on the same basis as citizens."); Richard A. Boswell, Restrictions on NonCitizens' Access to Public Benefits, 42 UCLA L. REv. 1475, 1492-93 (1994) ("It was not until approximately 1972 that Congress began to enact restrictions on access to benefit programs based on either immigration or citizenship status."); see also Tanya Broder et al., , Overview of Immigrant Eligibility for Federal Programs, NAT'L IMMIG. L. CTR. (2015), https://www.nilc.org/wpcontent/uploads/2015/12/overview-immeligfedprograms-2015-12-09.pdf [https://perma.cc/H6QA5E9W].

62. Janet M. Calvo, Alien Status Restrictions on Eligibility for Federally Funded Assistance Programs, 16 N.Y.U. L. Rev. \& Soc. Change 395, 418 (1987-88) ("The first federal restriction on the availability of Medicaid to aliens was a regulation which limited eligibility to legal permanent residents and aliens permanently residing in the United States under color of law.”) (citing 45 C.F.R. $\S 248$ (1973)).

63. Omnibus Budget Reconciliation Act, Pub. L. No. 97-35, § 2320(a)(3), 95 Stat. 357, 857 (1981) (codified as amended 42 U.S.C. § 602(a)(33) (Supp. IV 1986) (limiting eligibility for AFDC to aliens who are permanent residents or "permanently residing in the United States under color of law" (PRUCOL)); Fox, supra note 61, at 1057 ("By 1948 only Texas barred noncitizens from ADC benefits"); Boswell, supra note 61, at 1489 ("In order to be eligible, a dependent child and all in his or her 'assistance unit' must be either U.S. citizens, lawful permanent residents, or PRUCOL ... [I]t seems that deportable persons who are present and allowed to remain in the United States with the knowledge of the INS may be eligible to receive benefits under PRUCOL.") (internal citations omitted).

64. Boswell, supra note 61 , at 1490 (describing immigration status eligibility criteria for Food Stamp recipients, which were more restrictive than for the other programs mentioned); Calvo, supra note 62, at 402-03 (describing restrictions on the eligibility of aliens for Food Stamps before and after the Immigration Reform and Control Act of 1986).

65. Calvo, supra note 62, at 408 ("In 1981, Congress limited the eligibility for federally assisted housing programs to aliens in specific statuses.") (citing 42 U.S.C. § 1436a(a) (1982)).

66. See Fox, supra note 61, at 1053 ("When the modern welfare state was established in 1935 no federal laws barred non-citizens, even unauthorized immigrants, from social assistance.”).

67. See id. at 1054 ("The roots of federal restriction ... stretch back to the 1960 s, when 
access to federal public benefits, including Supplemental Security Income ("SSI") - a new program - in 1972, ${ }^{68}$ Medicaid and AFDC in 1973, Food Stamps in 1974, federal unemployment insurance in $1976 .{ }^{69}$

In 1996, Congress passed welfare reform legislation that severely restricted lawful immigrants' access to federal public benefits. ${ }^{70}$ These restrictions aimed to reduce federal spending on public benefit programs and to deter noncitizens from coming to the United States to access public benefits. ${ }^{71}$ The Personal Responsibility and Work Opportunity Reconciliation Act ("PRWORA") created two categories of immigrants for purposes of eligibility for federal public benefits: qualified aliens and non-qualified aliens. ${ }^{72}$ The term "qualified alien" does not originate in immigration law, and the category includes noncitizens with many different types of statuses, including lawful permanent residents and humanitarian immigrants such as refugees and asylees. ${ }^{73}$ Qualified aliens are barred from eligibility for federal public benefits until five years after the date they become qualified, a provision commonly referred to as the "five-year bar." In general, non-qualified aliens are not eligible for federal programs that provide

changes in immigration and welfare policy led to an unexpected rise in unauthorized migration and an expansion of the welfare rolls.").

68. Social Security Amendments of 1972, Pub. L. No. 92-603, § 1614(a)(1)(B)(ii), 86 Stat. 1329, 1471; Supplemental Security Income for the Aged, Blind, and Disabled, 52 Fed. Reg. 21,939 (June 10, 1987), 20 C.F.R. § 416.1618 (1988) (stating that aliens are eligible for SSI if they are permanent residents, temporary residents, special agricultural workers, replenishment agricultural workers, or PRUCOL); Fox, supra note 61, at 1055 (describing how "[f]or almost four decades social security officials interpreted [the Act] to mean that unauthorized immigrants were . . . eligible for" programs administered by the SSA); Boswell, supra note 61, at 1490.

69. Fox, supra note 61, at 1059; see Boswell, supra note 61, at 1492-93; Calvo, supra note 62, at 418, 420-21 (regarding restrictions on the eligibility of aliens for Medicaid from 1973-1988 and for AFDC from 1981-1987).

70. Personal Responsibility and Work Opportunity Reconciliation Act of 1996, 8 U.S.C. $\S$ 1612 (1996).

71. H.R. REP. No. 104-430, at 146 (1995), as reprinted in 1996 U.S.C.C.A.N. 2105, 2260 (describing the two main objectives of PRWORA as "to assure that aliens be self-reliant in accordance with national immigration policy . . . [and] to remove the incentive for illegal immigration provided by the availability of public benefits."). However, it is far from certain whether restricting immigrant eligibility for public benefits accomplishes either goal, a topic I explore in prior work. See Medha D. Makhlouf, Health Justice for Immigrants, 4 U. PENN. J.L. \& Pub. AfF. 235, 266-71 (2019).

72. Personal Responsibility and Work Opportunity Reconciliation Act of 1996, Pub. L. No. 104-193, 110 Stat. 2105 (Aug. 22, 1996) (codified as amended in scattered sections of 42 U.S.C.).

73. PRWORA $\S 431$ (b), 110 Stat. at 2274 (codified in 8 U.S.C. $\S 1641(b)$ ); see also William Wilberforce Trafficking Victims Protection Reauthorization Act of 2008, Pub. L. No. 110-457, 122 Stat. $5063 \S 211$ (Dec. 23, 2008) (adding certain survivors of trafficking to the definition of “qualified alien").

74. PRWORA $\S 431,110$ Stat. 2105, 2274 (codified in 8 U.S.C. $§ 1641$ ). Exemptions from the five-year bar to certain categories of immigrants, such as refugees and asylees. 8 U.S.C. $\S 1612$. 
"any retirement, welfare, health, disability, public or assisted housing, postsecondary education, food assistance, unemployment benefit, or any other similar benefit." ${ }^{.75}$ However, certain federally funded programs that support health and well-being remain accessible to noncitizens regardless of status. ${ }^{76}$ These include emergency Medicaid; public health programs that provide immunizations and treatment of communicable disease symptoms; school breakfast and lunch programs; K-12 public education; the Special Supplemental Nutrition Program for Women, Infants, and Children ("WIC"); short-term non-cash emergency disaster assistance; and Head Start. ${ }^{77}$

This dramatic - but not total - restriction on immigrants' eligibility for federal public benefits necessitated clarification from the INS about how use of public benefits would impact inadmissibility and deportability under the public charge ground. In 1999, the INS released a Field Guidance defining a "public charge" as "an alien who has become (for deportation purposes) or who is likely to become (for admission or adjustment purposes) 'primarily dependent on the government for subsistence, as demonstrated by either the receipt of public cash assistance for income maintenance, or institutionalization for long-term care at government expense."'"78 This policy accurately reflects the historical principles underlying public charge, in that it takes into consideration use of public benefits that would indicate "a complete, or nearly complete, dependence on the Government rather than the mere receipt of some lesser level of financial support." "79 Under this policy, which is still in effect, immigration officers consider use of public benefits as a factor in the public charge determination only if an applicant for adjustment of status has received SSI, cash assistance from Temporary Assistance for Needy Families ("TANF," the successor to AFDC), state or local cash assistance programs for income maintenance, or Medicaid for long-term care in a nursing home or mental health institution. ${ }^{80}$ INS reached this decision after consulting with the Social Security Administration, the Department of Health and Human Services, and the Department of Agriculture, concluding that "non-cash benefits generally provide supplementary support in the form of vouchers or direct services to support nutrition, health, and living condition needs." ${ }^{\prime 1}$ There was also an implicit understanding that such benefits "are often

75. PRWORA $\S 401(\mathrm{c})(1)(B), 110$ Stat. at 2113 (codified in 42 U.S.C. $\S 601$ ).

76. 8 U.S.C. $\S \S 1611(\mathrm{~b}), 1613(\mathrm{c})$.

77. Id.; see also 83 Fed. Reg. 51,128, Table 3 (listing programs that are exceptions from the definition of federal public benefit under PRWORA); 83 Fed. Reg. 51,131-32 (describing exempted programs in detail).

78. Field Guidance on Deportability and Inadmissibility on Public Charge Grounds, 64 Fed. Reg. 28,689 (May 26, 1999). See also Dep't of State, 9 FAM 302.8-2(B)(1)(a)(1) (defining “public charge" in the same way).

79. Inadmissibility and Deportability on Public Charge Grounds, 64 Fed. Reg. 28,676, 28,677 (May 26, 1999).

80. Id.

81. Id. at 28,677-78. Public benefits that are not currently considered in the public charge determination include Medicaid: public health services; use of community health clinics; short-term 
provided to low-income working families to sustain and improve their ability to remain self-sufficient." 82 Provision of such benefits to noncitizens - even during a period of increasing concern over the costs of social welfare programs and the volume of new immigrants - was understood as the nation's "commitment to assist members of our communities who fall on hard times," and not as a basis for punitive immigration consequences. ${ }^{83}$

Relatedly, humanitarian immigrants such as refugees and asylees who are exempt from the five-year bar on eligibility for federal public benefits are also exempt from the public charge grounds of inadmissibility and deportation. ${ }^{84}$ It is broadly understood that such immigrants often come into the country with few resources, and that providing immediate access to public benefits to them without any risk of negative immigration consequences is good policy for promoting their long-term self-sufficiency.

\section{PUBLIC HEALTH CONCERNS IN THE DEVELOPMENT OF PUBLIC CHARGE POLICY}

Public health concerns have influenced the development of public charge policy. Public health is defined as what "we as a society do collectively to assure the conditions in which people can be healthy." ${ }^{\prime 55}$ Public benefits programs are a collectively-funded safety net designed to promote public health and create other positive effects on society by addressing the social determinants of health ("SDoH"). ${ }^{86}$ The World Health Organization defines $\mathrm{SDoH}$ as "the conditions in which people are born, grow, work, live, and age, and the wider set of forces and systems shaping the conditions of daily life." ${ }^{87}$ The $\mathrm{SDoH}$ are widely

rehabilitation services; prenatal care and emergency medical services; CHIP; nutrition programs; housing benefits; child care services; energy assistance; emergency disaster relief; foster care and adoption assistance; educational assistance; job training programs; in-kind, community based programs such as soup kitchens, crisis counseling, etc.; non-cash benefits under TANF (subsidized child care or transit subsidies); earned cash payments such as Social Security; government pensions and veterans benefits; and unemployment compensation. Hester et al., supra note 11, at 7-8.

82. 64 Fed. Reg. at 28,678. See also id. at 28,678 ("Non-cash benefits . . are by their nature supplemental and frequently support the general welfare.").

83. Hester et al., supra note 11 , at 9 . By highlighting these assumptions underlying the development of public charge policy, I do not intend to minimize the problematic way in which public charge has been used to exclude "undesired" groups throughout the nation's history. This is due in part to the broad, readily abusable discretion that consular and border officials have in making public charge determinations. See, e.g., Douglas C. Baynton, Defectives in the Land: Disability and American Immigration Policy, 24 J. AM. ETHNiC Hist. 31, 33 (2005).

84. 8 U.S.C. $\S 1613(b)(1)$ (2019) (exemption from five-year bar); 8 U.S.C. § 1182(a)(4) (2019) (exemption from public charge ground of inadmissibility).

85. Inst. of Med., The Future of Public Health (1998).

86. See generally Elizabeth H. Bradley \& Lauren A. Taylor, The American Health Care Paradox: Why Spending More Is Getting Us Less (2013).

87. Social Determinants of Health, World HeAlth ORG., https://www.who.int/social_ 
acknowledged to have a significant effect on individual and population health, although the precise mechanisms of causation are complex and not fully understood. ${ }^{88}$

The laws governing public benefit programs, which redistribute public resources to ameliorate the grossest inequalities in society (lack of basic necessities like food and shelter) are prime examples of "incidental health law," or "policies that are not primarily focused on health, but may nonetheless be creating health benefits or harms." ${ }^{99}$ Although immigration laws are less commonly considered incidental health laws, public charge policy is unique in that, for a significant subpopulation within the United States, it can directly influence the decision to access subsidized health coverage and other healthpromoting public benefits. ${ }^{90}$ Section II.A describes the relationship between financial resource strain, the $\mathrm{SDoH}$, and public benefit programs. Section II.B identifies instances in which the INS and its successor, the DHS, have explicitly and implicitly recognized public health rationales in developing public charge policy.

\section{A. Financial Resource Strain and Social Determinants of Health}

Public benefit programs address SDoH by providing direct services, vouchers, or cash benefits to people who are experiencing financial resource strain. The American Public Health Association ("APHA") has referred to the services provided by public benefit programs as "the bedrock of the public health infrastructure." 91 There is an "extensive body of research recognizing that enrollment in public assistance programs contributes to positive health outcomes,

determinants/en/ [https://perma.cc/W84G-8FYG].

88. See Secretary's Advisory Committee on National Health Promotion and Disease Prevention Objectives for 2020, U.S. Dep't of Health \& Human SeRv. (July 26, 2010), http://www.healthypeople.gov/2010/hp2020/advisory/SocietalDeterminantsHealth.htm [https://perma.cc/F7C3-DXNX]; Scott Burris, Law in a Social Determinants Strategy: A Public Health Law Research Perspective, 126 PUB. HeAlth ReP. 22, 26 (2011) ("There is unquestionably a need for more study of social determinants, their complex role in causing health outcomes, and the effectiveness of policy changes in addressing them.").

89. Burris, supra note 88 , at 26.

90. Changes in federal policy regarding immigrant access to public benefits in the 1970s led immigrant communities to delay care: "“[w]ithin the tightly knit' immigrant community "word spread quickly about the danger of visits to health centers. Many people . . . heard of someone who had been deported when they had sought . . . treatment at a health center.' Medical students at Irvine noted the dangers of delayed care. And the dean of the medical center reported feeling 'disgust, shame, and anger' at being pressured to 'implement what are essentially immigration service functions." Fox, supra note 61, at 1069 (describing a 1974 study of access to medical care for undocumented immigrants in Orange County, California). In a forthcoming work, I plan to explore this phenomenon of "health care system avoidance" among noncitizens in detail.

91. Am. Pub. Health Ass'n, supra note 8. 
economic mobility, and self-sufficiency." 92 The public benefit programs that DHS proposes to consider in public charge determinations impact public health in many ways.

Access to affordable health insurance supports public health. Medicaid, the means-tested public health insurance program, is "an essential source of health insurance for low-income individuals and families, children, pregnant women, individuals with disabilities, and other underserved population groups" in the United States, covering one-fifth of the population. ${ }^{93}$ Health coverage enables enrollees to access a wide array of health services they otherwise might not be able to afford. ${ }^{94}$ For example, studies have found that Medicaid increases access to preventative care such as well-child visits and cancer screenings, ${ }^{95}$ and that it is associated with a broad array of improved health outcomes, from fewer hospitalizations ${ }^{96}$ and emergency department visits ${ }^{97}$ to improved oral health. ${ }^{98}$ Access to health coverage through Medicaid also lifts families out of poverty, which can shield children from adverse experiences and "toxic stress" that can

92. Id.

93. Nat'l Health Law Program Team, National Health Law Program Comments Filed on Proposed Public Charge Rule Change, Nat'L. Health L. Program (Dec. 10, 2018), https:/healthlaw.org/resource/national-health-law-program-comments-filed-on-proposed-publiccharge-rule/ [https://perma.cc/R2M9-G9J6].

94. Id.

95. Julia Paradise, Data Note: Three Findings about Access to Care and Health Outcomes in Medicaid, Henry J. KAISER FAM. Found. (Mar. 23, 2017), https://www.kff.org/medicaid/issuebrief/data-note-three-findings-about-access-to-care-and-health-outcomes-in-medicaid/ [https://perma.cc/9HVG-MF9A].

96. Sarah Miller \& Laura R. Wherry, The Long-Term Effects of Early Life Medicaid Coverage 3-4 (2015), http://www-personal.umich.edu/ mille/MillerWherry_Prenatal2015.pdf [https://perma.cc/9QLC-UBAZ] (finding that "in utero Medicaid coverage lowers hospitalizations for conditions that have been previously shown to be sensitive to the in utero environment").

97. Laura R. Wherry et al., Childhood Medicaid Coverage and Later Life Health Care Utilization, 287 (Nat'l Bureau of Econ. Research, Working Paper No 20929, 2015), https://www.nber.org/papers/w20929.pdf [https://perma.cc/M5XR-BP3Z] (finding that more years of childhood eligibility for Medicaid among blacks is associated with a $7 \%$ to $15 \%$ decrease in hospitalizations and $2 \%$ to $5 \%$ decrease in emergency department visits).

98. Brandy J. Lipton et al., Previous Medicaid Expansion May Have Had Lasting Positive Effects on Oral Health of Non-Hispanic Black Children, 35 HeAlth AfF. 2249, 2249 (2016), https://www.academyhealth.org/files/Health\%20 Aff-2016-Lipton-2249-58.pdf [https://perma.cc/8V7C-8CPY]. For a review of studies examining the impact of Medicaid expansion, see Olena Mazurenko et al., The Effects of Medicaid Expansion under the ACA: A Systematic Review, 37 Health AfF. 944 (2018); and Larisa Antonisse et al., The Effects of Medicaid Expansion under the ACA: Updated Findings from a Literature Review, HENRY J. KAISER FAM. FOUND. (Mar. 28, 2018), https://www.kff.org/medicaid/issue-brief/the-effects-of-medicaidexpansion-under-the-aca-updated-findings-from-a-literature-review-march-2018/ [https://perma.cc/DUF5-JX6Z] (finding that "multiple new studies demonstrate a positive association between expansion and health outcomes."). 
affect their health later in life. ${ }^{99}$ Ultimately, Medicaid has been found to improve population health through its positive effects on enrollees' health behaviors, access to care, and health outcomes. ${ }^{100}$ The compound effect of Medicaid coverage is improved socioeconomic mobility for children. ${ }^{101}$

The Supplemental Nutrition Assistance Program (SNAP or food stamps) is the nation's largest and most important anti-hunger program; in 2015, SNAP lifted 8.4 million people out of poverty, reducing the poverty rate by 17 percent. ${ }^{102}$ By supplementing the food budgets of millions of families across the country, SNAP "improves dietary quality, protects against obesity, and improves health, especially among children." ${ }^{103}$ Food insecurity is associated with common and costly health problems such as diabetes, heart disease, obesity, hypertension, chronic kidney disease, and depression. ${ }^{104}$ By addressing food insecurity directly, SNAP is an important piece of a public health strategy to reduce the incidence of these common and costly health problems. ${ }^{105}$

Public housing programs subsidize the cost of rent for low-income tenants in order to counter the effects of housing instability. ${ }^{106}$ Such programs are "a critical

99. Karina Wagnerman, Alisa Chester, \& Joan Alker, Medicaid is a Smart Investment in Children, Geo. U. Health Pol'y Inst. Ctr. FOR Child. And Families (Mar. 2017), https://ccf.georgetown.edu/wp-content/uploads/2017/03/MedicaidSmartInvestment.pdf [https://perma.cc/NZ2J-J3FY].

100. Sara R. Collins, Munira Z. Gunja, Michelle M. Doty, \& Sophie Beutel, Americans' Experiences with ACA Marketplace and Medicaid Coverage: Access to Care and Satisfaction, THE COMmonweALTh Fund (May 25, 2016) https://www.commonwealthfund.org/publications/issuebriefs $/ 2016 / \mathrm{may} /$ americans-experiences-aca-marketplace-and-medicaid-coverage [https://perma.cc/4HUK-SFCT].

101. Sarah Miller \& Laura R. Wherry, The Long-Term Effects of Early Life Medicaid Coverage, J. Hum. Resources (2018).

102. Laura Wheaton \& Victoria tran, The Antipoverty Effects of the Supplemental Nutrition Assistance Program (2018) https://www.urban.org/sites/ default/files/publication/96521/the_antipoverty_effects_of_the_supplemental_nutrition_assistan ce_program_3.pdf [https://perma.cc/VTQ2-SA9S].

103. Food Res. \& Action Ctr., The Role of Supplemental Nutrition Assistance Program in Improving Health and Well-Being (2017), http://frac.org/wp-content/uploads/ hunger-health-role-snap-improving-health-well-being.pdf [https://perma.cc/HH6J-PDL5].

104. Id.

105. 7 U.S.C. $\S 2011$ ("It is hereby declared to be the policy of Congress, in order to promote the general welfare, to safeguard the health and well-being of the Nation's population by raising levels of nutrition among low-income households ... [t]o alleviate such hunger and malnutrition, a supplemental nutrition assistance program is herein authorized which will permit low-income households to obtain a more nutritious diet through normal channels of trade by increasing food purchasing power for all eligible households who apply for participation."); The Food Stamp Act of 1964, 88 Pub. L. No. 525, 78 Stat. 703; Food Res. \& ACTION CTR., supra note 103.

106. Housing Instability, HeAlthyPeoPle.gov, https://www.healthypeople.gov/2020/topicsobjectives/topic/social-determinants-health/interventions-resources/housing-instability\#6 [https://perma.cc/26KA-PHKS]. 
lifeline" to recipients who are living through a national affordable housing crisis that is expected to continue growing. ${ }^{107}$ The National Housing Law Project reports that "[h]aving safe and stable housing is crucial to a person's good health, their ability to sustain employment, and overall self-sufficiency." 108 A body of research shows that housing instability causes increased hospital visits, mental health problems, and loss of employment, and that it negatively impacts children's cognitive development. ${ }^{109}$ By subsidizing the cost of housing, public housing programs directly address the root cause of housing instability.

Public benefits that provide or subsidize the costs of health care, food, and housing work together to ensure stability for working families. ${ }^{110}$ For example, families that are able to access housing assistance and nutrition benefits are 72 percent more likely to experience housing stability. ${ }^{111}$ Similarly, individuals with access to affordable health coverage are 25 percent less likely to miss a rent payment. ${ }^{12}$

While each public benefit program described here has been shown to have positive impacts on public health, their combined impact is greater than their sum. Together, they "serve as investments in social and individual well-being and future productivity."

107. Nat'l Housing Law Project, Comments in Response to Proposed Rulemaking: Inadmissibility on Public Charge Grounds 1, 3 (Dec. 10, 2018), https://www.nhlp.org/wpcontent/uploads/NHLP-Comments-on-Proposed-Rule-on-Public-Charge.pdf [https://perma.cc/L42L-A4TJ].

108. Id. at $4-5$.

109. See Will Fischer, Research Shows Housing Vouchers Reduce Hardship and Provide Platform for Long-Term Gains Among Children, CTR. ON Budget \& Pol'y PRiorities, https://www.cbpp.org/research/housing/research-shows-housing-vouchers-reduce-hardship-andprovide-platform-for-long-term [https://perma.cc/Z2CS-3CLC] (last updated Oct. 7, 2015); LINDA Giannarelli et al., Reducing Child Poverty in the US: Costs and Impacts of Policies Proposed By the ChILDREN's DeFEnSE Fund (Jan. 2015), https:/www.urban.org/sites/default/ files/publication/39141/2000086-Reducing-Child-Poverty-in-the-US.pdf [https://perma.cc/49TMFDKF]; Heather Sandstrom \& SAndra Huerta, The Negative EFfects of Instability on Child Development: A Research Synthesis (2013), https:/www.urban.org/sites/default/ files/publication/32706/412899-The-Negative-Effects-of-Instability-on-Child-Development-AResearch-Synthesis.PDF [https://perma.cc/7MHX-7KXS].

110. Nat'1 Housing Law Project, supra note 107, at 6.

111. Megan Sandel et al., Co-enrollment for Child Health: How Receipt and Loss of Food and Housing Subsidies Relate to Housing Security and Statutes for Streamlined, Multi-subsidy Application, 5 J. Applied RES. ON CHILD. 2, 7 (2014).

112. Kriston Capps, For the Poor, Obamacare Can Reduce Late Rent Payments, CityLaB (Dec. 4, 2018), https://www.citylab.com/equity/2018/12/obamacare-health-insurance-housing-rentpayments/577099/ [https://perma.cc/MKD3-Y7PU].

113. Nat'1 Housing Law Project, supra note 107, at 10. 


\section{B. Chilling Effects}

The nexus of immigration law and public benefits law is incredibly complex. ${ }^{114}$ Confusion about which immigrant statuses qualify for which benefits is a frequent source of error at state welfare agencies. ${ }^{115}$ Likewise, noncitizens themselves are often unaware of whether they qualify for various benefits, ${ }^{116}$ and whether enrolling in public benefits could have negative consequences for future immigration applications. ${ }^{17}$ Proposed expansions of the types of public benefits that are considered in public charge determinations have sown confusion among noncitizens and have been associated with a marked decrease in public benefits enrollment. ${ }^{118}$ This effect is observed in noncitizens who are directly impacted by

114. See, e.g., Andrew Hammond, The Immigration-Welfare Nexus in a New Era?, 22 LEWIS \& CLARK L. REV. 501, 503 (2018) ("mapping the unpredictable landscape of noncitizen eligibility for public benefits"); TANYA Booker, Avideh Moussavian, \& JONATHAN BLAZER, Overview of Immigrant Eligibility for Federal Programs, NILC, 7, https:/www.nilc.org/wp-content/uploads/ 2015/12/overview-immeligfedprograms-2015-12-09.pdf [https://perma.cc/39RC-L34K] (last updated Dec. 2015) (“Confusion about eligibility rules pervades benefit agencies and immigrant communities. The confusion stems from the complex interaction of the immigration and welfare laws, differences in eligibility criteria for various state and federal programs, and a lack of adequate training on the rules as clarified by federal agencies.").

115. Tanya Broder et al., Overview of Immigrant Eligibility for Federal Programs, National Immigration Law Center, 7 (2015), https://www.nilc.org/wp-content/uploads/2015/12/overviewimmeligfedprograms-2015-12-09.pdf [https://perma.cc/4R7J-Y74Q]. ("[M]any . . . eligibility workers have turned away eligible immigrants mistakenly."); $i d$. at 8 (describing how benefit agencies sometimes misinterpret verification requirements relating to immigration or citizenship status). There are credible reports that in the past, INS and State Department officials have erroneously excluded persons from entering the United States under the public charge ground based on their usage of non-cash public assistance. Claudia Schlosberg \& DinAH Wiley, The ImPaCT of INS Public Charge Determinations on Immigrant Access to Health Care (1998).

116. Broder et al., supra note 115 , at 7.

117. Id. (describing how " $[\mathrm{t}]$ he misapplication of [the] public charge ground of inadmissibility immediately after [PRWORA] passed contributed significantly to the chilling effect on immigrants' access to services").

118. See Neeraj Kaushal \& Robert Kaestner, Welfare Reform and Health Insurance of Immigrants, 40 HeAlth SERV. RES. 697 (Jun. 2005), https://www.ncbi.nlm.nih.gov/pmc/articles/ PMC1361164/ [https://perma.cc/V6P4-EM44]; Michael E. Fix \& Jeffrey S. Passel, Trends in Noncitizens' and Citizens' Use of Public Benefits Following Welfare Reform, Urb. Inst. (Mar. 1, 1999), https://www.urban.org/research/publication/trends-noncitizens-and-citizens-use-publicbenefits-following-welfare-reform [https://perma.cc/VP4P-EPJ3]; Namratha R. Kandula et al., The Unintended Impact of Welfare Reform on the Medicaid Enrollment of Eligible Immigrants, 39 HEALTH SERV. RES. 1509 (Oct. 2004), https://www.ncbi.nlm.nih.gov/pmc/articles/PMC1361081/ [https://perma.cc/KD3Z-ATLM]; Rachel Benson Gold, Immigrants and Medicaid After Welfare Reform, GutTMACHER INST. (May 1, 2003), https:/www.guttmacher.org/gpr/2003/05/immigrantsand-medicaid-after-welfare-reform [https://perma.cc/H7N5-LZCM]; Inadmissibility on Public Charge Grounds, 83 Fed. Reg. 51,114 (proposed Oct. 10, 2018). In its proposed rule, DHS notes 
changes in law as well as by those who are not directly impacted. ${ }^{119}$ This latter effect, in which noncitizens disenroll from or forgo enrollment in public benefits for which they qualify is called a "chilling effect." ${ }^{120}$ Uncertainty about possible consequences of enrollment in public benefits drives the chilling effect. ${ }^{121}$

Members of mixed-status families (families in which members have different citizenship or immigration statuses) are particularly susceptible to the chilling effect, because although some members of the family (e.g. U.S. citizens) may qualify for benefits and are not subject to public charge, others may not be eligible or may be subject to public charge, and this complexity may discourage decision makers from applying for benefits for any member of the family. ${ }^{122}$ Children are particularly at risk of negative health consequences of this chilling effect, because although noncitizen children are typically eligible for a broader array of public benefits compared with adults, their parents tend to control decisions about enrollment. ${ }^{123}$

Even if parents enroll their children in public benefits but choose not to enroll themselves, any negative effects on parents' health and well-being will inevitably impact their children. ${ }^{124}$ Studies have found that early childhood exposure to "toxic stress," or "strong, frequent, and/or prolonged adversity . . . without adequate adult support," can interfere with brain development. ${ }^{125}$ Economic

that studies of the chilling effect of welfare reform in 1996 caused enrollment reductions in public benefit programs ranging from $21-54 \%$.

119. See, e.g., Samantha Artiga et al., Estimated Impacts of the Proposed Public Charge Rule on Immigrants and Medicaid, KAISER FAM. FOUND., 3 (2018), http://files.kff.org/attachment/IssueBrief-Estimated-Impacts-of-the-Proposed-Public-Charge-Rule-on-Immigrants-and-Medicaid [https://perma.cc/2YLJ-375F].

120. See, e.g., Jeanne Batalova et al., Chilling Effects: The Expected Public Charge Rule and Its Impact on Legal Immigrant Families' Public Benefits Use, Migration PoL'y Inst. (2018), https://www.migrationpolicy.org/sites/default/files/publications/ProposedPublicChargeRule_Fin alWEB.pdf [https://perma.cc/DV8W-D4HU].

121. Id.

122. See, e.g., Kathleen R. Page \& Sarah Polk, Chilling Effect? Post-Election Health Care Use by Undocumented and Mixed-Status Families, 376 NEw EnG. J. MED. e20 (2017) (describing how, post-PRWORA, undocumented immigrant parents declined to enroll their U.S. citizen children in public benefits because they were "reluctant to interact with staff at public agencies or to enter their information in government databases"); id. (predicting that the current "climate of deportation may dampen the use of existing resources, even among eligible people").

123. Id.

124. Steven D. Cohen, Applying the Science of Child Development in Child Welfare Systems, Ctr. on Dev. ChILD. HARv. U., 10-11 (OCt. 2016), http://www.caichildlaw.org/Misc/Dec2016 RT_Harvard_Brief.pdf [https://perma.cc/X8WW-UYU7] (describing how parents of children who have been abused or neglected are often facing powerful external stressors, and that public assistance that helps them meet basic needs can "allow[] them to focus on longer-term priorities such as building the skills needed to care effectively for their children.”).

125. Jack P. Shonkoff et al., The Lifelong Effects of Early Childhood Adversity and Toxic Stress, AAP NEWs \& Journals GATEWAY, e236-37 (Jan. 2012), http://pediatrics.aappublications. 
instability, food insecurity, and health problems can exacerbate toxic stress responses. ${ }^{126}$

Changes in public charge law can undermine individual and population health if people who are not subject to public charge consequences refuse to apply for or disenroll from public benefits that support health, nutrition, and economic stability. For example, one common misunderstanding of public charge is that it applies when a lawful permanent resident applies for naturalization (to become a U.S. citizen). This error was reported widely in the media following the release of the proposed public charge rule in October 2018. ${ }^{127}$ Even some naturalized U.S. citizens expressed concern over whether their receipt of public benefits could put their U.S. citizenship at risk.

The development of public charge policy has reflected a broad public policy strategy of improving health and nutrition in order to help working-poor families become self-sufficient. ${ }^{128}$ Law and policy that disincentivizes noncitizens from enrolling in public benefits is a structural determinant of health that is predicted to be extremely costly in the long term.

\section{Public Health Rationale}

In its 1999 Field Guidance, INS made explicit the public health rationale underlying its interpretation of the statutory provisions establishing the public charge grounds of inadmissibility and deportability. At the outset, INS claimed that its reasons for providing this interpretation to the public were "to reduce the negative public health consequences generated by the existing confusion and to provide aliens with better guidance as to the types of public benefits that will and will not be considered in public charge determinations." 129 By "negative public health consequences," INS meant the result of noncitizens foregoing enrollment

org/content/129/1/e232 [https://perma.cc/7JGD-LP6X] (defining toxic stress); Toxic Stress, CTR. ON DEV. ChILD. HARV. U., https://developingchild.harvard.edu/science/key-concepts/toxic-stress/ [https://perma.cc/V2R7-TUPP] (describing impact of toxic stress on brain architecture).

126. See, e.g., Excessive Stress Disrupts the Architecture of the Developing Brain, CTR. ON Dev. Child. Harv. U., 3 (Jan. 2014), https://46y5eh11 fhgw3ve3ytpwxt9r-wpengine.netdnassl.com/wp-content/uploads/2005/05/Stress_Disrupts_Architecture_Developing_Brain-1.pdf [https://perma.cc/7D59-2SVD] ("Children who grow up in conditions of economic hardship often exhibit elevated stress hormone levels."). A characteristic toxic stress response is "strong, frequent, or prolonged activation of the body's stress management system." Id. at 2.

127. See, e.g., Khushbu Shah, Alarmist Reporting Turns Immigrants Away From Social Services, Officials Say, Colum. Journalism Rev. (Nov. 28, 2018), https://www.cjr.org/ covering_the_health_care_fight/wic-immigrants.php [https://perma.cc/5GAU-5SRJ]; New "Public Charge" Rules Shouldn't Affect Travel Plans for Current Permanent Residents, SANCTUARY SANTA CRUZ (Nov. 19, 2018), https://sanctuary-sc.net/cab-public-charge/ [https://perma.cc/AS78BR7N].

128. Inadmissibility and Deportability on Public Charge Grounds, 64 Fed. Reg. 101, 28,678 (1999)

129. Id. at 28,689 . 
in benefits due to fears of negative immigration consequences under the public charge law. ${ }^{130}$ INS was particularly concerned about noncitizens' fears of accessing “emergency and other medical assistance, children's immunizations, and basic nutrition programs, as well as the treatment of communicable diseases." "131 INS also noted that noncitizens were being deterred from other health-supporting benefits such as child care and transportation vouchers. ${ }^{132}$ Hence, public health considerations were a motivating factor behind the standards that the INS proposed in the 1999 Field Guidance, which remains the current policy.

\section{THE PROPOSED PUBLIC CHARGE RULE AS A DEPARTURE FROM LONGSTANDING POLICY}

DHS released a proposed rule on October 10, 2018, that would dramatically alter longstanding public charge policy in the inadmissibility context. ${ }^{133}$ The intent of the proposed changes is "to better ensure that aliens subject to the public charge inadmissibility ground are self-sufficient." 134 DHS purports to do this by making the public charge test less discretionary and by expanding the number of noncitizens who would be excluded under the public charge ground. ${ }^{135}$ The rule aims to achieve some of the policy changes that the Trump administration has unsuccessfully sought to implement through Congress, such as limiting familybased immigration by moving to a "merit-based" immigration system."

Notably, the rule would change the longstanding definitions of "public charge" and "public benefit." The proposed definition of "public charge" would change the meaning of the term from "primarily dependent on the government" to "an alien who receives one or more public benefits." 136 In addition, the proposed rule expands the types of public benefits that would be considered in the public charge determination. ${ }^{137}$ DHS describes this change as an improvement to the current policy, which it considers to be "insufficiently protective of the public budget, particularly in light of significant public expenditures on non-cash benefits." 138 Historically, the only types of public benefits that have been

130. Id.

131. Id. at 28,676 .

132. Id. at 28,677 .

133. See Inadmissibility on Public Charge Grounds, 83 Fed. Reg. 51,114 (proposed Oct. 10, 2018).

134. Id. at 51,116 .

135. See Proposed Change to Public Charge Ground of Inadmissibility, U.S. CITIZENSHIP AND IMMIGR. SERVICES, https://www.uscis.gov/legal-resources/proposed-change-public-charge-groundinadmissibility/ [https://perma.cc/7PZQ-4VNV] (last updated Oct. 16, 2018) (stating that "there has been insufficient guidance on how to determine if an alien who is applying for a visa, admission, or adjustment of status is likely at any time to become a public charge").

136. Inadmissibility on Public Charge Grounds, 83 Fed. Reg. at 51,157-58.

137. See id. at 51,159 .

138. Inadmissibility on Public Charge Grounds, 83 Fed. Reg. at 51,164.. 
considered in the analysis are those that provide cash benefits or long-term institutionalization. ${ }^{139}$ The proposed rule would also consider use of nonemergency Medicaid (with exceptions for certain disability-related services), Premium and Cost Sharing Subsidies for Medicare Part D, the Supplemental Nutrition Assistance Program (SNAP), and housing assistance such as public housing and Section 8 vouchers. ${ }^{140}$ These benefit programs are vitally important for supporting health, nutrition, and economic stability among low-income households. In addition, the proposed rule provides more specific guidance on how to weigh certain factors in the "totality of the circumstances" test. One such guidance is to treat any public benefit enrollment within the previous thirty-six months as a "heavily weighed negative factor."141

The following sections describe the predicted impact of the proposed rule on public benefits enrollment among noncitizens, summarize the ways in which the proposed rule represents a departure from longstanding public charge policy, and caution against abandoning the public health rationale that has influenced the development of public charge policy for over a century.

\section{A. Predicted Impact}

Comments submitted to DHS by prominent advocacy groups in response to the proposed rule emphasize its predicted adverse effect on public health. ${ }^{142} \mathrm{~A}$ major concern is the "chilling effect" of the proposed rule, i.e. that noncitizens will be discouraged from accessing public benefits out of fear of, or confusion about, negative immigration consequences. ${ }^{143}$ Research findings on the health effects of prior changes in law that chilled access to public benefits predict that the proposed rule would have a disproportionate impact on the health outcomes of single mothers, pregnant women, and children. ${ }^{144}$ The chilling effect of the

139. See supra text accompanying notes 52-55.

140. Inadmissibility on Public Charge Grounds, 83 Fed. Reg. at 51,164.

141. Id. at 51,199-200.

142. See, e.g., CMS-9922-P, Patient Protection and Affordable Care Act; Exchange Program Integrity NPRM, NAT'L HEALTH L. ProgRAM (Jan. 8, 2019), https://9kqpw4dcaw91s37kozm5jx17wpengine.netdna-ssl.com/wp-content/uploads/2019/01/2019-Exchange-Program-IntegrityComments-FINAL.pdf [https://perma.cc/TE36-T7U8]; DHS Docket No. USCIS-2010-0012, RIN 1615-AA22, Comments in Response to Proposed Rulemaking: Inadmissibility on Public Charge Grounds, Aм. PuB. HeAlth Ass'N, 4-5 (Dec. 10, 2018), https://apha.org/-/media/files/pdf/ advocacy/testimonyandcomments/181210_apha_public_charge_comments.ashx?la=en\&hash $=5$ 6A1A126FC49D31E1766368617B2284942A01B70 [https://perma.cc/7V4P-3ZVK] ("The direct impact and chilling effect of this proposed rule threatens to erode decades of progress made in improving the public's health.").

143. DHS Docket No. USCIS-2010-0012, RIN1615-AA22, Comments in Response to Proposed Rulemaking: Inadmissibility on Public Charge Grounds, supra note 141.

144. Paul Wise et al., Assessing the Effects of Welfare Reform Policies on Reproductive and Infant Health, 89 AM. J. PuB. HeALth 1514 (1999); Kimberly Narain et al., The Impact of Welfare Reform on the Health Insurance Coverage, Utilization and Health of Low Education Single 
proposed rule is expected to result in dire public health consequences such as increases in maternal mortality, premature birth, low birth weight, behavioral and emotional problems among children, mental health issues, metabolism-related illnesses, and inflammatory diseases like arthritis. ${ }^{145}$ These negative health outcomes are expected to cause disproportionate harm to people of color, exacerbating existing disparities in health outcomes. ${ }^{146}$

For some, fear of accessing public benefits arises from confusion about who the current or proposed public charge policy affects, or which benefits are considered in the public charge determination process. Media reports and anecdotal evidence support the claim that confusion is the source of a decrease in enrollment in public benefit programs by applicants for naturalization, by ineligible parents on behalf of their U.S. citizen children, and by noncitizens of all types enrolled in programs that are not considered in the inadmissibility determination in the current or proposed rule. ${ }^{147}$

For others, however, declining to enroll in or disenrolling from public benefit programs - regardless of the impact of the current or proposed rule - may be considered a rational response to the Trump administration's pronouncements on public charge, which date back to January 2017. At that time, a draft executive order, "Protecting Taxpayer Resources by Ensuring Our Immigration Laws Promote Accountability and Responsibility," was leaked to the media. ${ }^{148}$ The order, which was never signed or released, directed the Secretary of Homeland Security to rescind existing field guidance on public charge and to propose a new rule that "specifies that an alien is inadmissible as a public charge if he is likely to receive, and is deportable as a public charge if he does receive, public benefits for which eligibility or amount is determined in any way on the basis of income, resources, or financial need[.." ${ }^{149}$ For this reason, many noncitizens reasonably anticipated a change in the rules that would penalize them for use of any meanstested public benefit. Revisions to the Department of State's Foreign Affairs Manual in January 2018 reflected the policy preferences in the executive order

Mothers, 180 Soc. SCI. \& MED. 28 (2017).

145. CMS-9922-P, Patient Protection and Affordable Care Act; Exchange Program Integrity NPRM, supra note 141 , at 57-61.

146. Id. at 63-65.

147. See, e.g., Helena Bottemiller Evich, Immigrants, Fearing Trump Crackdown, Drop Out of Nutrition Programs, PoLITICO, https://www.politico.com/story/2018/09/03/immigrants-nutritionfood-trump-crackdown-8062922 [https://perma.cc/676B-2D34] (last updated Sept. 4, 2018, 1:29 PM.

148. See, e.g., Matthew Yglesias \& Dara Lind, Read Leaked Drafts of Four White House Executive Orders on Muslim Ban, End to DREAMer Program, and More, VOX (Jan. 25, 2017, 5:43 PM), https:/www.vox.com/policy-and-politics/2017/1/25/14390106/leaked-drafts-trumpimmigrants-executive-order [https://perma.cc/XB46-X5LH].

149. Memorandum from Andrew Bremburg, Assistant to the President and Dir. of the Domestic Policy Council, to President Donald Trump (Jan. 23, 2017), https://cdn3.vox-cdn.com/ uploads/chorus_asset/file/7872571/Protecting_Taxpayer_Resources_by_Ensuring_Our_Immigr ation_Laws_Promote_Accountability_and_Responsibility.0.pdf [https://perma.cc/C3KD-SPAP]. 
by permitting its officials abroad to consider use of all public benefits by applicants or their dependent family members in public charge assessments. ${ }^{150} \mathrm{In}$ February and March 2018, two drafts of a public charge rule were leaked to the media; both drafts carried out the directive of the draft executive order to consider use of any means-tested public benefit in the public charge assessment. ${ }^{151}$ Both drafts also included use of public benefits by applicants' dependent family members, including U.S. citizen children. ${ }^{152}$ These periodic releases of information, although questionably reliable, were in line with the Trump Administration's stated policy goal of reducing noncitizen enrollment in public benefit programs. With this background, one can understand why a noncitizen who is not subject to the current or proposed public charge policy would choose to avoid the use of public benefits. There is a rational fear among noncitizens that public charge policy could become more punitive over time or could be applied retroactively.

DHS acknowledges the possibility that its proposed rule could chill immigrant enrollment in public benefits:

Research shows that when eligibility rules change for public benefits programs there is evidence of a "chilling effect" that discourages immigrants from using public benefits programs for which they are still eligible ... [I]t is unclear how many individuals would actually disenroll from or forego enrollment in public benefits programs due to the proposed rule . . . PRWORA was directly changing eligibility requirements whereas this proposed rule, if finalized, would change enrollment incentives. ${ }^{153}$

If the proposed rule is finalized as written, noncitizens who will have to undergo a public charge determination in the future will certainly be incentivized to refrain from enrolling in certain benefits. This will be a difficult decision for some families, as the American Public Health Association notes in its public comment submitted in response to the proposed rule: "The fear generated by this rule would put families in impossible situations where they are forced to choose between keeping their families together or enrolling in programs to keep their families healthy." ${ }^{154}$ However, DHS fails to recognize that noncitizens who are

150. Access to Health Care, Food, and Other Public Programs for Immigrant Families Under the Trump Administration, NAT'L IMMIGR. L. CTR. (Mar. 22, 2017), https://www.nilc.org/ issues/health-care/exec-orders-and-access-to-public-programs/ [https://perma.cc/L6Z7-P2BN].

151. Id.

152. Id.

153. Inadmissibility on Public Charge Grounds, 83 Fed. Reg. at 51,266 (emphasis added).

154. Comment Letter on Proposed Rulemaking: Inadmissibility on Public Charge Grounds from Georges C. Benjamin, Executive Director of the American Public Health Association, to Samantha Deshommes, Chief of the Regulatory Coordination Division of the Office of Policy and Strategy at U.S. Citizenship and Immigration Services, Department of Homeland Security, at 2 (Dec. 10, 2018), https://apha.org/-/media/files/pdf/advocacy/testimonyandcomments/181210_ apha_public_charge_comments.ashx [https://perma.cc/E26Z-T56L]. 
not subject to public charge inadmissibility would also be chilled from enrolling in benefits. ${ }^{155}$

It is estimated that if the proposed public charge role is finalized as written, the magnitude of disenrollment caused by the chilling effect would dwarf the number of noncitizens who are actually subject to public charge inadmissibility. ${ }^{156}$ For example, disenrollment from Medicaid and the Children's Health Insurance Program on account of the proposed rule is estimated to be between 2.1 and 4.9 million. ${ }^{157}$ This includes as many as two million eligible U.S. citizen children with immigrant parents who disenroll out of fear of immigrationrelated consequences. ${ }^{158}$ More tragically, it is possible that even if the proposed public charge rule is never finalized as written, its major effect will be to have chilled public benefits use for millions of noncitizens. A chilling effect has already been observed in response to leaked drafts of the proposed public charge rule. ${ }^{159}$ There are widespread reports of noncitizens avoiding public benefits use out of fear of immigration consequences. ${ }^{160}$

155. See, e.g., Comment Letter on Inadmissibility on Public Charge Grounds from Elizabeth G. Taylor, Executive Director of the National Health Law Program, to U.S. Citizenship and Immigration Services, Department of Homeland Security, at 44 (Dec. 10, 2018), https:// 9kqpw4dcaw91s37kozm5jx17-wpengine.netdna-ssl.com/wp-content/uploads/2018/12/NationalHealth-Law-Program-Public-Charge-Comments-FINAL-12.10.18.pdf [https://perma.cc/J8SD4PVK] (NHeLP stating "DHS wrongly ignores the fact that family members and communities surrounding noncitizens will stop using public benefits, even though they are not directly targeted by the proposed rule.").

156. See, e.g., id. at 44 (estimating that " $[\mathrm{t}] \mathrm{h}$ he proposed rule will directly affect approximately 1.1 million individuals seeking to obtain lawful permanent resident (LPR) status" compared with potentially "14 million noncitizens and their family members whose household incomes fall below 125 percent of [Federal Poverty Guidelines].").

157. ARTiga ET AL., supra note 5.

158. Samantha Artiga et al., Potential Effects of Public Charge Changes on Health Coverage for Citizen Children (Henry J. Kaiser Family Foundation, 2018), http://files.kff.org/attachment/Issue-Brief-Potential-Effects-of-Public-Charge-Changes-on-HealthCoverage-for-Citizen-Children [https://perma.cc/XM9R-QQGP].

159. See, e.g., Evich, supra note 146; Taylor, supra note 154.

160. See, e.g., Mitchell H. Katz \& Dave A. Chokshi, The "Public Charge" Proposal and Public Health Implications for Patients and Clinicians, JAMA (Oct. 1, 2018) https:// championprovider.ucsf.edu/sites/champion.ucsf.edu/files/wysiwyg/JAMA\%20The\%20public\% 20charge \%20proposal\%20Katz\%2C\%20M\%202018.pdf [https://perma.cc/RRL9-HSJD]; Evich, supra note 146; Ileana Najarro \& Jenny Deam, Fearing Deportation, Undocumented Immigrants in Houston are Avoiding Hospitals and Clinics, Houston Chronicle, https://www. houstonchronicle.com/news/houston-texas/houston/article/Fearing-deportation-undocumentedimmigrants-are-12450772.php [https://perma.cc/4DUQ-JPRV] (last updated Dec. 28, 2017, 11:00 A.M.). 


\section{B. Disregard for Public Health Rationale}

The proposed rule is premised on one of the dual principles that have endured for more than a century of public charge policy: the desire to attract and retain immigrants who will be self-sufficient through employment. ${ }^{161}$ However, in drafting the rule, DHS ignored a critical insight that also has influenced the development of public charge policy. This is the understanding that public benefits play an important role in helping the working poor to become selfsufficient in the long term by addressing $\mathrm{SDoH}$, such as access to health care and adequate nutrition. The development of public charge policy has historically reflected a broad public policy strategy of improving health and nutrition in order to help working-poor families become self-sufficient. ${ }^{162}$

One indication of DHS's oversight is the proposed change to the definition of public charge, which shifts the focus of the analysis from dependence on government support ("primarily dependent") to any use of public benefits ("receives one or more public benefits"). ${ }^{163}$ The proposed rule states that enrollment in benefits "even in a relatively small amount or for a relatively short duration would in many cases be sufficient to render a person a public charge."164 This statement is inconsistent with historical understandings of dependence in the public charge context and ignores evidence indicating the contributing role of public benefits to long-term self-sufficiency. Mere use of public benefits, divorced from any analysis of the degree to which such use indicates a need for long-term support, has never been a focal point of the public charge analysis. Receipt of health-supporting public benefits has been understood to supplement the basic needs of working poor families and support them on the path to selfsufficiency. ${ }^{165}$ As a result, in the inadmissibility context, use of public benefits is one factor in the "totality of circumstances" test-a factor that is possible to overcome if other evidence, such as employment history, indicates that the applicant is not likely to become primarily dependent on the government for support. ${ }^{166}$

Similarly, the proposed rule's inclusion of a broad array of public benefits in the public charge determination disregards the connection between public benefits, improved health, and long-term self-sufficiency by stating that use of

161. See Historians' Comment passim, supra note 10.

162. Inadmissibility and Deportability on Public Charge Grounds, 64 Fed. Reg. 28, 676, 28, 678. (May 26, 1999).

163. Inadmissibility on Public Charge Grounds, 83 Fed. Reg. at 51,157-58.

164. Inadmissibility on Public Charge Grounds, 83 Fed. Reg. at 51,164. This statement is inconsistent with historical understandings of dependence in the public charge context and ignores evidence indicating the contributing role of public benefits to long-term self-sufficiency.

165. Field Guidance on Deportability and Inadmissibility on Public Charge Grounds, 64 Fed. Reg. at 28, 692.

166. Application for Adjustment from Temporary to Permanent Resident Status, 8 C.F.R. $\S$ 245a.3(g)(4)(i)-(iii) (2019). 
virtually any public benefit "evidence[s] a lack of self-sufficiency."167 DHS correctly notes that "[f]ood, shelter, and necessary medical treatment are basic necessities of life." 168 However, it then jumps to the conclusion that "[a] person who needs the public's assistance to provide for these basic necessities is not selfsufficient." 169 This conclusion relies on DHS's definition of "self-sufficient," which refers to those who "do not depend on public resources to meet their needs, but rather rely on their own capabilities and the resources of their family, sponsor, and private organizations." ${ }^{\prime 70}$ This tautological reasoning ignores the substantial evidence, upon which the INS relied in its 1999 Field Guidance, that people with a broad range of incomes receive public benefits to subsidize basic necessities in order to maintain good health and achieve self-sufficiency: "Certain Federal, State, and local benefits are increasingly being made available to families with incomes far above the poverty level, reflecting broad public policy decisions about improving general health and nutrition, promoting education, and assisting working-poor families in the process of becoming self-sufficient." ${ }^{171}$ The ACA represents the latest manifestation of this trend of expanding eligibility for public benefits to a broader swath of families on the income spectrum. Its premium subsidy for coverage purchased in the Health Insurance Marketplace is available to households with resources up to 400 percent of the federal poverty line. ${ }^{172}$ This reform addresses inefficiencies in the health insurance market that would otherwise make health insurance unaffordable.

In the proposed rule, DHS acknowledges that its changes will likely cause great harm to individuals, families, and communities. ${ }^{173}$ Specifically, it states that disenrollment and foregone enrollment in public benefits will likely lead to:

- Worse health outcomes, including increased prevalence of obesity and malnutrition, especially for pregnant or breastfeeding women, infants, or children, and reduced prescription adherence;

- Increased use of emergency rooms and emergent care as a method of primary health care due to delayed treatment;

- Increased prevalence of communicable diseases, including among members of the U.S. citizen population who are not vaccinated;

- Increases in uncompensated care in which a treatment or service is not paid for by an insurer or patient;

- Increased rates of poverty and housing instability; and

167. Inadmissibility on Public Charge Grounds, 83 Fed. Reg. 51,114, 51,159 (Oct. 10, 2018) (to be codified at 8 C.F.R. pts. 103, 212, 213, 214, 245 and 248) (DHS proposes that some shortterm or very small dollar amount of benefits may be excluded from public charge determinations).

168. Id. at 51,159.

169. Id.

170. Id. at 51,122.

171. Inadmissibility and Deportability on Public Charge Grounds, 64 Fed. Reg. at 28,678.

172. Internal Revenue Service, Eligibility for the Premium Tax Credit, https://www.irs.gov/ affordable-care-act/individuals-and-families/eligibility-for-the-premium-tax-credit [https://perma.cc/5B2B-FEK9] (last updated Feb. 14, 2019).

173. Inadmissibility on Public Charge Grounds, 83 Fed. Reg. at 51,270. 
- $\quad$ Reduced productivity and educational attainment. ${ }^{174}$

Despite acknowledging these explicit harms, and "the importance of increasing access to health care and helping people to become self-sufficient in certain contexts (such as respect to other agencies' administration of government assistance programs)," DHS concludes that it is not required to advance those goals through public charge policy. ${ }^{175}$ However, this statement is explicitly counter to its predecessor agency's interpretation of the decades-long history of public charge policy. Moreover, it devalues larger developments in social welfare and public health policy that have sought to improve access to health care and health-supporting public benefits among all members of the community, and specifically for vulnerable members of the community. Such policies, which increase government spending on public benefits, are justified by their net economic benefits for society.

The proposed rule reflects a divergent agenda, devoted to slashing enrollment in health-supporting public benefits among citizens and noncitizens alike in the name of "self-sufficiency." This broader agenda is evident in an executive order signed by President Trump in April 2018, which announced policy support for strengthening work requirements in programs across the welfare system. ${ }^{176}$ The Center for Medicare \& Medicaid Services (CMS) had already taken this position, releasing policy guidance in January 2018 to support state efforts to impose work or community engagement (volunteer) requirements as a condition of Medicaid eligibility. ${ }^{177}$ CMS's policy guidance grossly misinterprets the relationship between public benefits, health outcomes, and self-sufficiency. It justifies its position based on studies indicating that employment and community engagement are correlated with improved health outcomes. ${ }^{178}$ However, researchers have cautioned against drawing the conclusion that work requirements would help to improve health and well-being among Medicaid beneficiaries; this is because correlation does not imply causation and evidence on the effect of employment

174. $I d$.

175. Id. at 51,158, n. 258.

176. Executive Order Reducing Poverty in America by Promoting Opportunity and Economic Mobility, 83 Fed. Reg. 15941 (Apr. 10, 2018). The U.S. Department of Agriculture (USDA) had already begun reviewing its options for stricter work requirements for recipients of SNAP on the date that the executive order was signed. In February 2019, USDA proposed a rule to broaden its work requirement, with the goal of "moving more able-bodied recipients of [SNAP] benefits to self-sufficiency through the dignity of work." Proposed Rule: SNAP Requirements for Able-Bodied Adults Without Dependents, USDA, https://www.fns.usda.gov/snap/fr-020119 [https://perma.cc/ Z4N7-UKDJ].

177. Letter from Brian Neale, Deputy Administrator and Director, Center for Medicaid and CHIP, to State Medicaid Directors (Jan. 11, 2018), https://www.medicaid.gov/federal-policyguidance/downloads/smd18002.pdf [https://perma.cc/2KKY-YSWS]. Support for work requirements in Medicaid represents a major shift in policy, as CMS had rejected state requests to impose such requirements in the past. $I d$. at 3.

178. $I d$. at $2,3,7$. 
on health is limited. ${ }^{179}$

There is much stronger evidence relating to the opposite effect: that access to subsidized health insurance such as Medicaid enables low-wage workers to obtain and retain employment. ${ }^{180}$ Research consistently shows that Medicaid enrollment is associated with "improved financial well-being, not a lack of selfsufficiency." 181 Indeed, Medicaid enrollment "produces net positives for the public budget over time both by increasing revenue collection and by decreasing government expenditures for incomes supports and costs of delayed and uncompensated care"- a conclusion that contrasts sharply with the cost-cutting rationale used to justify the administration's proposed policies in the immigration and welfare contexts. ${ }^{182}$ In addition, experts in poverty law and policy have strongly denounced work requirements in welfare programs, characterizing them as "ill-informed, ineffective, inefficient, and inequitable." 183

Nevertheless, as of January 2019, sixteen states have applied to the Secretary of Health and Human Services (HHS) for Section 1115 Medicaid demonstration waivers that would permit them to condition Medicaid on meeting a work requirement. ${ }^{184}$ One state, Arkansas, has implemented its work requirement, and an early analysis shows that few people obtained new jobs and many people lost their health insurance as a result of the requirement. ${ }^{185}$ In March 2019, Judge James E. Boasberg of the U.S. District Court for the District of Columbia ruled against the Secretary's approval of work requirements in Arkansas and Kentucky in two separate opinions and halted the implementation of the work requirement in Arkansas. ${ }^{186}$ In both cases, the Court found that the Secretary failed to address the programs' potential to cause substantial numbers of people to lose their health

179. See, e.g., Larisa Antonisse and Rachel Garfield, The Relationship Between Work And Health: Findings from a Literature ReView (Henry J. Kaiser Family Foundation, 2018), http://files.kff.org/attachment/Issue-Brief-The-Relationship-Between-Work-and-HealthFindings-from-a-Literature\%20Review [https://perma.cc/Z754-JZXN]; Heather HAHN ET AL., Work Requirements in Social Safety Net Programs (Urban Institute, 2017) https://www. urban.org/sites/default/files/publication/95566/work-requirements-social-safety-net-programs_4.pdf [https://perma.cc/HMB8-KLSH].

180. ANTONISSE \& GARFIELD, supra note 177.

181. Taylor, supra note 154 , at 10.

182. Id. at 12 .

183. See, e.g., Grant Et Al., UnWorkable \& Unwise: Conditioning ACCESS to Programs THAT ENSURE A BASIC Foundation FOR FAMILIES ON WORK REQUIREMENTS (Georgetown Center on Poverty and Inequality, 2019) http://www.georgetownpoverty.org/wp-content/uploads/2019/ 02/Unworkable-Unwise-20190201.pdf [https://perma.cc/P7ZP-QVEM].

184. Id. at 11 .

185. An Early Look at the Impact: New Medicaid Work Requirement Hurts Health Coverage in ARKansas 3 (Arkansas Advocates for Children \& Families, 2018), http://www. aradvocates.org/publications/medicaid-work-requirement-arkansas-hurts-health-coverage/ [https://perma.cc/DHZ6-GTNA].

186. Gresham v. Azar, 363 F. Supp. 3d 165 (D.C. Cir. 2019); Stewart v. Azar (“Stewart II”), 2019 WL 1375496 (D.C. Cir.). 
coverage. ${ }^{187}$ This effect would contradict the main purpose of Medicaid, which is to provide medical assistance to people who cannot afford it. ${ }^{188}$

Significantly, in both opinions the Court explicitly recognizes the role of health coverage in promoting financial self-sufficiency. In Gresham v. Azar, the challenge to the approval of the Arkansas Works Amendments, the opinion opens with the story of Adrian McGonigal, an Arkansas resident who was terminated from Medicaid for failure to report his employment. ${ }^{189}$ As a result, he was unable to afford his prescriptions, his health conditions flared up, he missed several days of work, and was ultimately fired by his employer because of his absences. ${ }^{190} \mathrm{In}$ Stewart II, the Court notes that even if self-sufficiency were an objective of Medicaid and "some number of beneficiaries were to gain independence, the Secretary does not weigh the benefits of their self-sufficiency against the consequences of coverage loss, which would harm and undermine the financial self-sufficiency of others." 191

By including Medicaid among the benefits to be considered in the public charge determination, the proposed rule implicitly discourages low-wage noncitizen workers from enrolling in health benefits that can shield them from risks of job loss that are associated with untreated health care needs. ${ }^{192}$ The Trump administration's selective reading of the body of the body of evidence on the relationship between work and health suggests that its agenda is not really motivated by a long-term strategy to reduce government spending on public benefits.

Another reason to suspect that economic efficiency is not the true driver of the proposed public charge rule is DHS's inclusion of federal housing assistance programs among the benefits to be considered in the public charge determination. ${ }^{193}$ DHS cites statistics on noncitizen enrollment in federal housing assistance programs to support its decision. ${ }^{194}$ However, DHS acknowledges that the statistics indicate that "noncitizen participation in these programs is currently

187. Stewart II, 2019 WL 1375496 at 14; Gresham, 363 F. Supp. 3d 165 at 18-20.

188. See 42 U.S.C. $§ 1396-1$ (describing the purpose of Medicaid). In approving Kentucky's waiver, the HHS Secretary relied, in part, on an objective external to the program's purpose: "financial self-sufficiency." Stewart II, 2019 WL 1375496 at 29. The Secretary did not rely on this objective in approving Arkansas' waiver, but did respond to public comments opposing the work requirements by stating that they "create appropriate incentives for beneficiaries to gain employment." Gresham, 363 F. Supp. 3d 165 at 18 (quoting Letter from Seema Verma, Administrator, Ctrs. for Medicare \& Medicaid Serv., to Cindy Gillespie, Director, Ark. Dep't of Human Serv. 5 (Mar. 5, 2018)); id. at 25 ("Nowhere in the Secretary's approval letter does he justify his decision based on ... a belief that the project will help Medicaid-eligible persons to gain sufficient financial resources to be able to purchase private insurance.").

189. Gresham, 363 F. Supp. 3d 165 at 1-2.

190. Id.

191. Stewart II, 2019 WL 1375496 at 33.

192. See ANTONISSE \& GARFIELD, supra note 177.

193. See Inadmissibility on Public Charge Grounds, 83 Fed. Reg. at 51,158-9.

194. Id. at 51,167. 
relatively low." 195 Indeed, only $0.2 \%$ of noncitizens lived in Section 8 housing, while $0.4 \%$ of noncitizens lived in other federally subsidized housing. ${ }^{196}$ Through the lens that DHS has constructed in the proposed rule, these statistics should be interpreted to mean that noncitizens are generally self-sufficient in paying for housing and are therefore not responsible for significant expenditures on federal housing assistance programs. They indicate that the public funds devoted to subsidized housing are adequately protected by existing eligibility restrictions that prevent noncitizens from enrolling in these programs. Nevertheless, DHS proposes to include federal housing assistance programs because "the total Federal expenditure for the programs overall remains significant" and because "they relate to a basic living need (i.e., shelter)." ${ }^{197}$ Indeed, the cost of administering the proposed rule would likely exceed the federal funds that would be saved by including federal housing assistance programs in the public charge determination. By hyper-focusing on noncitizen use of public benefits to the exclusion of analyses of long-term self-sufficiency and impact on public resources, the proposed rule departs dramatically from the history and purpose of public charge. ${ }^{198}$

The current administration has framed its proposed public charge rule as a way to promote self-sufficiency among noncitizens by discouraging them from enrolling in safety net programs. ${ }^{199}$ Incidentally, they claim, the new policy would reduce federal and state government expenditures on public benefits. ${ }^{200}$ However, this Section has described reasons to infer that economic efficiency is not a genuine motivation for the proposed public charge rule. In the context of President Trump's anti-immigrant rhetoric and the accompanying rise of nativism, the proposed rule should be considered one strand of the

195. Id.

196. See id.

197. Id.

198. Press Release, Department of Homeland Security, DHS Announces New Proposed Immigration Rule to Enforce Long-Standing Law that Promotes Self-Sufficiency and Protects American Taxpayers (Sept. 22, 2018) https://www.dhs.gov/news/2018/09/22/dhs-announces-newproposed-immigration-rule-enforce-long-standing-law-promotes-self [https://perma.cc/HP86SYYB]. DHS's stated justification for the proposed rule is that the change would enable it to better carry out the Congressional intent of the public charge law, which DHS Secretary Kirstjen Nielsen describes as "promot[ing] immigrant self-sufficiency and protect[ing] finite resources" Id. I have described how the proposed changes to public charge policy do not appear to be calculated to achieve these ends. If the proposed rule is finalized as written, there is an argument to be made that DHS has exceeded its rulemaking power in promulgating the public charge rule. This topic is ripe for future exploration but is beyond the scope of this Essay.

199. See, e.g., 83 Fed. Reg. 51,116 ("DHS seeks to better ensure that aliens subject to the public charge inadmissibility ground are self-sufficient, i.e., do not depend on public resources to meet their needs.").

200. Id. at 51,122 (estimating that the changes would reduce federal and state government transfer payments by $\$ 2.27$ billion annually). 
administration's "self-deportation" policy agenda. ${ }^{201}$ Self-deportation is "a variety of state-sponsored coercive removal that assigns some agency to individuals in their own departure." 202 In practice, it involves legislating and regulating to make every aspect of life difficult for noncitizens so that they "self-deport" or avoid entering the country at all. ${ }^{203}$ By restricting or discouraging access to public benefits, the proposed rule has already inflicted suffering on millions of people living in the United States. From that perspective, regardless of whether the rule is finalized as written, it has already done its job.

\section{The Normative Case}

The second principle underlying public charge policy is the commitment to support members of the community who fall on hard times. ${ }^{204}$ As I have written elsewhere, noncitizens living in the United States are embedded in multiple overlapping and complex networks within American society. ${ }^{205}$ The noncitizens who are most likely to be affected by the proposed public charge rule are those who are applying for adjustment to lawful permanent resident status, who have lived in the United States for several years, and who have close personal and professional ties with U.S. citizens. ${ }^{206}$ They almost certainly live among citizens, attend school with citizens, work side-by-side with citizens; they have paid taxes to fund public programs that promote the general welfare; they have family members who are citizens. In short, they would be considered members of the community by their neighbors, colleagues, classmates, and family. Like many U.S. citizens, they may have fallen on hard times and relied on public benefits to supplement their income.

Insofar as solidarity with members of our communities is still considered a social good, and public benefits are recognized as a stepping stone to economic security rather than evidence of moral failure, public charge policy should continue to allow noncitizens to enroll in most public benefits without fear of

201. For a comprehensive history and analysis of self-deportation as a government strategy, see K-Sue Park, Self-Deportation Nation (2018) (manuscript on file with author).

202. Id. at 5-6.

203. See id. at 3 (quoting former Alabama state Representative Micky Hammon, who explained that H.B. 56, a law requiring police to attempt to determine a person's legal status if they have reasonable suspicion that the person is unlawfully present, was designed "[t]o make it difficult for them to live here so they will deport themselves").

204. See Historians' Comment passim, supra note 10.

205. Makhlouf, supra note 71, at 293-94 (2019).

206. In the context of noncitizen access to health care, solidarity-based arguments have certain limitations, described in detail in Patricia Illingworth \& Wendy E. Parmet, The Health of Newcomers: Immigration, Health Policy, and the Case for Global Solidarity (2017). For example, such arguments tend to rely on exclusivity - in this case, seeming to favor noncitizens who have resided in the United States for longer periods. Although it would be possible to extend my normative argument to noncitizens seeking admission from overseas, I do not attempt to do so here, as it is beyond the scope of this Essay. 
negative immigration consequences. Enabling access to health-supporting public benefits for all members of the community is not only critical for ensuring the long-term wellbeing of us all - it also embodies a moral commitment to solidarity with and compassion for the people who live among us.

\section{CONCLUSION}

Public charge law and policy have determined the admissibility and deportability of noncitizens ever since the federal government began comprehensively regulating immigration. Public charge policy has remained remarkably consistent over time, adhering to its dual principles: an effort to promote the entry of able-bodied and employable immigrants and, importantly, a commitment to assist members of the community who fall on hard times. Concern for public health has influenced the development of public charge policy over time. However, the changes to public charge policy proposed in October 2018 represent a departure from the policy's dual principles and its consideration of public health concerns. Rather, the proposed changes are tied to a broader agenda to restrict access to health-supporting public benefits generally, among citizens and noncitizens alike. 